
sta. 21

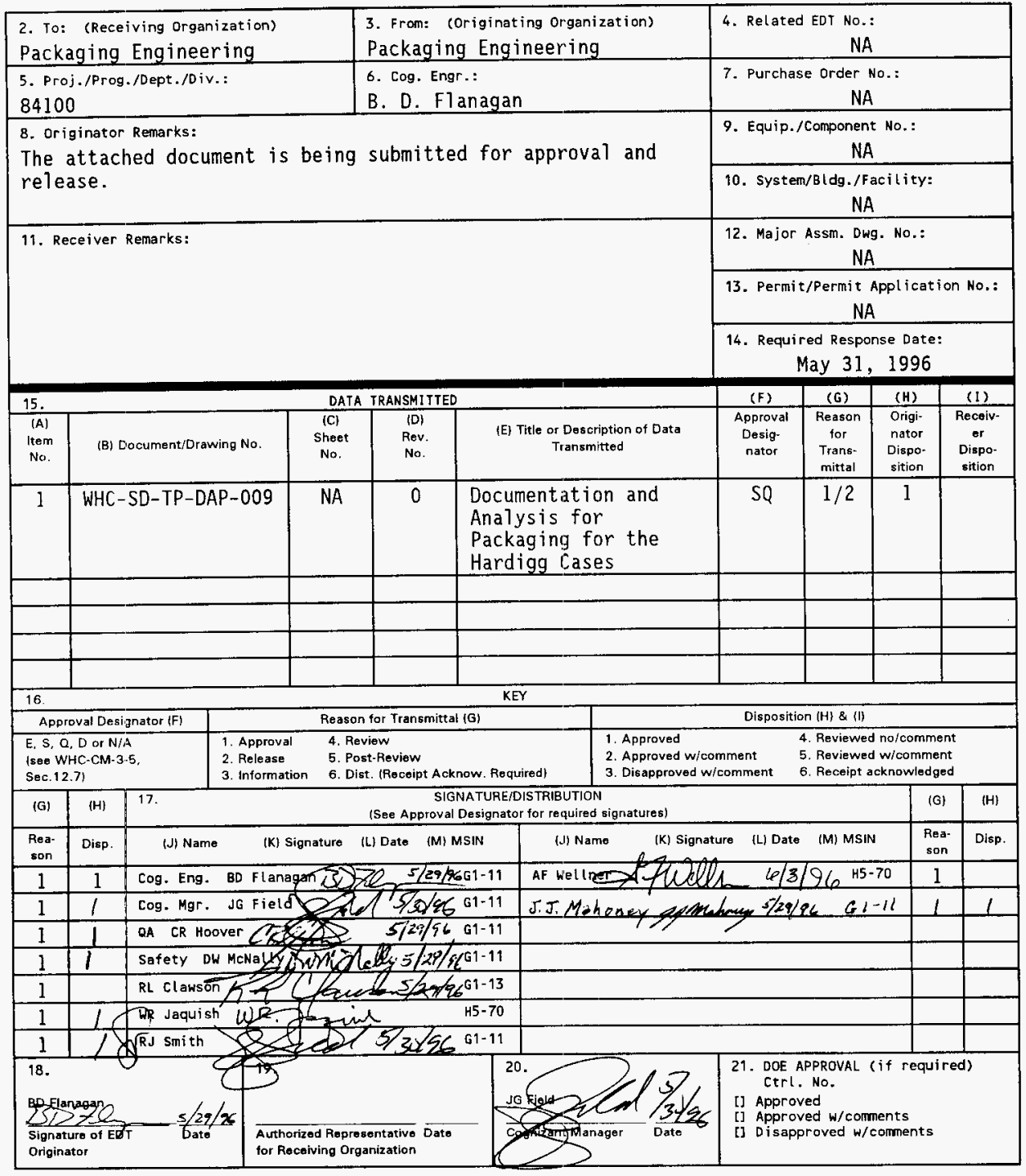

BD - 7400-172-2 (04/94) GEF097 


\section{Documentation and Analysis for Packaging for the Hardigg Cases}

\section{B. D. Flanagan}

Westinghouse Hanford Company, Richland, WA 99352

U.S. Department of Energy Contract DE-AC06-87RL10930

EDT/ECN: 615809

UC: 513

Org Code: 84100

B\&R Code: EW3120072

Charge Code: $\quad$ E44773

Total Pages: 19

Key Words: low specific activity, LSA, Industrial Packaging Type 1, IP-1, surface contaminated object, SCO, shipping

Abstract: This documentation and analysis for packaging documents that Hardigg cases meet the requirements for Industrial Packaging Type 1 containers for the packaging of 10 specific activity radioactive material or surface contaminated object quantities for transport.

TRADEMARK DISCLAIMER. Reference herein to any specific comercial product, process, or service by trade name, trademark, manufacturer, or otherwise, does not necessarily constitute or imply its endorsement, recommendation, or favoring by the United States Government or any agency thereof or its contractors or subcontractors.

Printed in the United States of America. To obtain copies of this document, contact: WHC/BCS Document Control Services, P.O. Box 1970, Mailstop H6-08, Richland WA 99352, Phone (509) 372-2420; Fax (509) 376-4989.
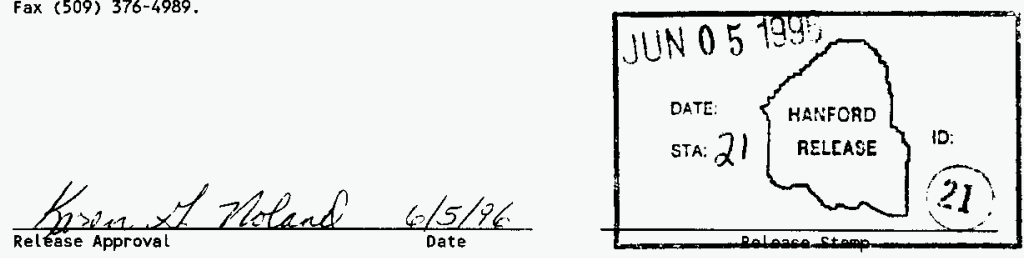


\section{CONTENTS}

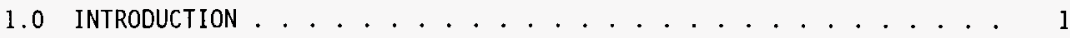

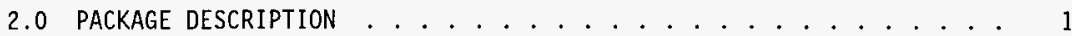

2.1 PACKAGING ..................... 1

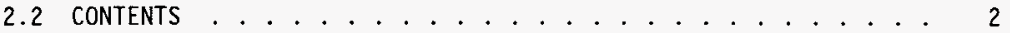

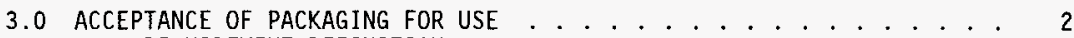

3.1 REQUIREMENT DEFINITIONS ................. . . 2

3.1 .1 Industrial Packaging Type $1 \ldots \ldots 2$

3.1 .2 Strong, Tight .............. . 4

4.0 TRANSPORTATION . . . . . . . . . . . . . . . . . . . 4

4.1 ORIGIN AND DESTINATION ..................... 4

4.2 REQUIREMENTS . . . . . . . . . . . . . . . . . . . . 4

4.2 .1 Contents .................. . . 4

4.2.2 Transportation . . . . . . . . . . . . . . . 6

4.2 .3 Loading and Unloading . . . . . . . . . . . . 9

4.2 .4 Tiedowns .................. . . 9

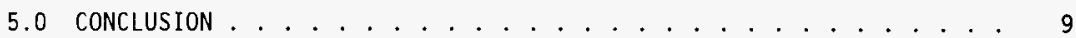

APPENDIX: HARDIGG CATALOG ............... A $\ldots$. . 
WHC-SD-TP-DAP-009 Rev. 0

\section{LIST OF TERMS}

$\begin{array}{ll}\text { cm } & \text { centimeter } \\ \text { DOT } & \text { U.S. Department of Transportation } \\ \text { in. } & \text { inch } \\ \text { IP-1 } & \text { Industrial Packaging Type 1 } \\ \text { IP-2 } & \text { Industrial Packaging Type } 2 \\ \text { IP-3 } & \text { Industrial Packaging Type } 3 \\ \text { kg } & \text { kilogram } \\ \text { Ib } & \text { pound } \\ \text { LSA } & \text { Iow specific activity } \\ \text { SCO } & \text { surface contaminated object }\end{array}$




\section{WHC-SD-TP-DAP-009 Rev. 0 \\ DOCUMENTATION AND ANALYSIS FOR PACKAGING \\ FOR THE HARDIGG' CASES}

\subsection{INTRODUCTION}

The purpose of this documentation and analysis for packaging is to document that Hardigg cases meet the U.S. Department of Transportation (DOT) 49 CFR 173.411 as Industrial Packaging Type 1 (IP-1) containers and strong, tight containers for the packaging of low specific activity (LSA) radioactive material or surface contaminated object $(\mathrm{SCO})$ quantities for transport. By meeting this requirement, LSA or SCO quantities of radioactive material can be shipped in compliance with WHC-CM-2-14, Hazardous Material Packaging and shipping, and the DOT regulations.

\subsection{PACKAGE DESCRIPTION}

\subsection{PACKAGING}

This document specifically considers Hardigg cases in the following size range (see appendix). The smallest size considered, case number AL1616-0412AC, has inside dimensions 16 in. $x 16$ in. $x 16$ in. $(40.64 \mathrm{~cm} \times$ $40.64 \mathrm{~cm} \times 40.64 \mathrm{~cm}[1 \times \mathrm{w} \times \mathrm{h}])$ and outside dimensions 19 in. $\times 19$ in. $\times 17.3$ in. $(48.26 \mathrm{~cm} \times 40.26 \mathrm{~cm} \times 43.94 \mathrm{~cm})$ and weighs $17.0 \mathrm{lb}(7.71 \mathrm{~kg})$. The largest size considered, case number AL2624-2724AC, has inside dimensions 26 in. $\times 24$ in. $\times 51.5 \mathrm{in} .(66.04 \mathrm{~cm} \times 60.96 \mathrm{~cm} \times 130.81 \mathrm{~cm})$ and outside dimensions of $29 \mathrm{in.} \times 27$ in. $\times 55.3 \mathrm{in} .(73.66 \mathrm{~cm} \times 68.58 \mathrm{~cm} \times 140.46 \mathrm{~cm})$ and weighs $58.31 \mathrm{~b}(26.44 \mathrm{~kg})$. Other sizes may be acceptable.

The cases are made of a molded durable polyethylene with corners that are 15\%-20\% thicker to absorb shocks more effectively. All hardware is fully recessed, including latches and handles. Stainless steel inserts are molded-in to give catches, hinges, and strikes added strength.

A tongue-in-groove gasketed parting line of each case provides a good seal. Each case will be free of any holes that could cause the container to "leak." The cases will be filled with polyethylene (closed cell) foam to provide cushioning and forms to hold the contents.

The gross weight of the package should not exceed $150 \mathrm{lb}(68.04 \mathrm{~kg})$ when using the handles for lifting and positioning. Each handle used for lifting is designed to carry $1501 \mathrm{~b}(68.04 \mathrm{~kg})$ with a margin of safety of 2 . Therefore, with two handles, the case will meet the design requirement of the handle margin of safety of 3 against yield when lifting the case.

\footnotetext{
${ }^{1}$ Hardigg is a tradenark of Hardigg Cases, a division of Hardigg Industries, Inc.
} 
WHC-SD-TP-DAP-009 Rev. 0

All items shall be bagged or wrapped in plastic before they are placed in the cases.

\subsection{CONTENTS}

Contents of the Hardigg cases must meet the requirements for which an IP-1 or strong tight container is authorized, specifically LSA or SCO (see 49 CFR 173.427).

\subsection{ACCEPTANCE OF PACKAGING FOR USE}

The Hardigg cases shall fulfill the design requirement for IP-1 (49 CFR 173.411).

\section{I REQUIREMENT DEFINITIONS}

In addition to the IP-1 requirements, there are specific requirements for al1 packages: 49 CFR 173.24, "General requirements for packagings and packages." Upon review of these requirements, no conflict was noticed with use of Hardigg cases.

\subsubsection{Industrial Packaging Type 1}

Industrial Packagings (49 CFR 173.411)

(a) General. Each industrial packaging must comply with the requirements of this section which specifies packaging tests, and record retention applicable to Industrial Packaging Type I (IP-1), Industrial Packaging Type 2 (IP-2), and Industrial Packaging Type 3 $(I P-3)$.

(b) Industrial packaging certification and tests. (1) Each IP-1 must meet the general design requirements prescribed in $\$ 173.410$.

(2) [NA] (IP-2)

(3) $[\mathrm{NA}](\mathrm{IP}-3)$

(4) [NA] (IM 101 or IM 102 portabie tank)

(5) [NA] (Freight container)

(c) [NA] No records retention requirements for IP-1.

General Design Requirements (49 CFR 173.410)

(a) The package can be easily handled and properly secured in or on a conveyance during transport. 
Acceptance: Each Hardigg case can be easily handled by using the handles provided at each end. Strapping may also be used to lift the cases. Proper securement can be accomplished by using strapping along with blocking and bracing on the conveyance.

(b) Each lifting attachment that is a structural part of the package must be designed with a minimun safety factor of three against yielding when used to lift the package in the intended manner, and it must be designed so that failure of any lifting attachment under excessive load would not impair the ability of the package to meet other requirements of this subpart. Any other structural part of the package which could be used to lift the package must be capable of being rendered inoperable for lifting the package during transport or must be designed with strength equivalent to that required for lifting attachments.

Acceptance: Each Hardigg case handle is rated for $1501 \mathrm{~b}(68.04 \mathrm{~kg})$ and fully recessed. The use of two handles will meet the safety factor of three against yield. Failure of the handles will not impair the case's ability to meet other requirements.

(c) The external surface, as far as practicable, wi7l be free from protruding features and will be easily decontaminated.

Acceptance: There are no unpracticable protruding features on the cases and each case is determined to be easily decontaminated.

(d) The outer layer of packaging will avoid, as far as practicable, pockets or crevices where water might collect.

Acceptance: There are no areas in which water may collect on the cases.

(e) Each feature that is added to the package will not reduce the safety of the package.

Acceptance: Not applicable. No features are being added to the case.

(f) The package will be capable of withstanding the effects of any acceleration, vibration or vibration resonance that may arise under normal conditions of transport without any deterioration in the effectiveness of the closing devices on the various receptacles or in the integrity of the package as a whole and without loosening or unintentionally releasing the nuts, boits, or other securing devices even after repeated use.

Acceptance: The Hardigg cases are made of a durable polyethylene and filled with a cushioning foam. Therefore, accelerations and vibrations from normal transport will have little or no effect on the cases.

(g) The materials of construction of the packaging and any components or structure will be physically and chemically compatible with each other and with the package contents. The behavior of the packaging and the package contents under irradiation will be taken into account. 
Acceptance: All materials used in the construction and components are fully compatible physically and chemically and there will be no degrading effects caused by the contents.

(h) [NA] (Valves)

(i) [NA] (Air transport)

\subsubsection{Strong, Tight}

There are no specific requirements for a strong, tight package other than being "strong" and "tight." The Hardigg cases have been shown to be "strong" by meeting the general design requirements of 49 CFR 173.410. The seamless design and tongue-in-groove seal show the leak-tight design, thus meeting the "tight" requirement.

\subsection{TRANSPORTATION}

\subsection{ORIGIN AND DESTINATION}

This document provides the necessary evaluation to show that the Hardigg cases described are acceptable for onsite and offsite transport.

\subsection{REQUIREMENTS}

The following requirements apply for transportation. Each applicable regulation and requirement is given below, along with its reference. Only the sections specifically applicable to the cases are listed. Additional transportation regulations and requirements, such as labeling and paperwork, applying to the general design and shipment of all packages are not provided here. It is the shipper's responsibility to ensure that shipments of the cases comply with all applicable regulations.

\subsubsection{Contents}

\section{Definitions (49 CFR 173.403)}

Low specific activity (LSA) material means Class 7 (radioactive) material with limited specific activity which satisfies the descriptions and limits set forth below. Shielding materials surrounding the LSA material may not be considered in determining the estimated average specific activity of the package contents. LSA material must be in one of three groups:

\section{(1) LSA-I.}


(i) Ores containing only naturally occurring radionuclides (e.g., uranium, thorium) and uranium or thorium concentrates of such ores; or

(ii) Solid unirradiated natural uranium or depleted uranium or natural thorium or their solid or liquid compounds or mixtures; or

(iii) Class 7 (radioactive) material, other than fissile material, for which the $A_{2}$ value is unlimited; or

(iv) Mill tailings, contaminated earth, concrete, rubble, other debris, and activated material in which the Class 7 (radioactive) material is essentially uniformly distributed and the average specific activity does not exceed $10^{-6} \mathrm{~A}_{2} / \mathrm{g}$.

(2) $L S A-I I$.

(i) Water with tritium concentration up to $0.8 \mathrm{TBq} / 7$ iter (20.0 Ci/liter); or

(ii) Material in which the Class 7 (radioactive) material is essentially uniformly distributed and the average specific activity does not exceed $10^{-4} A_{2} / g$ for solids and gases, and $10^{-5} A_{2} / g$ for Tiquids.

(3) LSA-III. Solids (e.g., consolidated wastes, activated materials) that meet the requirements of $\$ 173.468$ and which:

(i) The Class 7 (radioactive) material is essentially uniformly distributed throughout a solid or a collection of solid objects, or is essentially uniformly distributed in a solid compact binding agent (such as concrete, bitumen, ceramic, etc.); and

(ii) The Class 7 (radioactive) material is relatively insoluble, or it is intrinsically contained in a relatively insoluble materia7, so that, even under loss of packaging, the loss of Class 7 (radioactive) material per package by leaching when placed in water for seven days would not exceed $0.1 A_{2}$; and

(iii) The average specific activity of the solid does not exceed $2 \times 10^{-\underline{3}} A_{2} / g$.

Surface Contaminated Object (SCO) means a solid object which is not itself radioactive but which has class 7 (radioactive) material distributed on any of its surfaces. SCO must be in one of two groups with surface activity not exceeding the following limits.

(1) SCO-I: A solid object on which:

(i) The non-fixed contamination on the accessible surface averaged over $300 \mathrm{~cm}^{2}$ (or the area of the surface if less than $300 \mathrm{~cm}^{2}$ ) does not exceed $4 \mathrm{~Bq} / \mathrm{cm}^{2}$ ( $10^{-4}$ microcuries $\left./ \mathrm{cm}^{2}\right)$ for beta and gamma and low toxicity alpha emitters, or $0.4 \mathrm{~Bq} / \mathrm{cm}^{2}\left(10^{-5}\right.$ microcuries $\left./ \mathrm{cm}^{2}\right)$ for a)pha emitters; 
WHC-SD-TP-DAP-009 Rev. 0

(ii) The fixed contamination on the accessible surface averaged over $300 \mathrm{~cm}^{2}$ (or the area of the surface if less than $300 \mathrm{~cm}^{2}$ ) does not exceed $4 \times 10^{4} \mathrm{~Bq} / \mathrm{cm}^{2}$ ( 1.0 microcurie/ $\mathrm{cm}^{2}$ ) for beta and gamma and low toxicity alpha emitters, or $4 \times 10^{3} \mathrm{~Bq} / \mathrm{cm}^{2}$ ( 0.1 microcurie $/ \mathrm{cm}^{2}$ ) for all other alpha emitters; and

(iii) The non-fixed contamination plus the fixed contamination on the inaccessible surface averaged over $300 \mathrm{~cm}^{2}$ (or the area of the surface if less than $300 \mathrm{~cm}^{2}$ ) does not exceed $4 \times 10^{4} \mathrm{~Bq} / \mathrm{cm}^{2}$ ( 1 microcurie $/ \mathrm{cm}^{2}$ ) for beta and gamma and low toxicity alpha emitters, or $4 \times 10^{3} \mathrm{~Bq} / \mathrm{cm}^{2}\left(0.1 \mathrm{microcurie} / \mathrm{cm}^{2}\right)$ for all other alpha emitters.

(2) SCO-II: A solid object on which the limits for SCO-I are exceeded and on which:

(i) The non-fixed contamination on the accessible surface averaged over $300 \mathrm{~cm}^{2}$ (or the area of the surface if less than $300 \mathrm{~cm}^{2}$ ) does not exceed $400 \mathrm{~Bq} / \mathrm{cm}^{2}\left(10^{-2}\right.$ microcurie $\left./ \mathrm{cm}^{2}\right)$ for beta and gamma and low toxicity alpha emitters or $40 \mathrm{~Bq} / \mathrm{cm}^{2}\left(10^{-3}\right.$ microcurie/ $\left./ \mathrm{cm}^{2}\right)$ for all other alpha emitters;

(ii) The fixed contamination on the accessible surface averaged over $300 \mathrm{~cm}^{2}$ (or the area of the surface if 7 ess than $300 \mathrm{~cm}^{2}$ ) does not exceed $8 \times 10^{5} \mathrm{~Bq} / \mathrm{cm}^{2}\left(20 \mathrm{microcurie} / \mathrm{cm}^{2}\right)$ for beta and gamma and low toxicity alpha emitters, or $8 \times 10^{4} \mathrm{~Bq} / \mathrm{cm}^{2}$ ( 2 microcurie $/ \mathrm{cm}^{2}$ ) for all other alpha emitters; and

(iii) The non-fixed contamination plus the fixed contamination on the inaccessible surface averaged over $300 \mathrm{~cm}^{2}$ (or the area of the surface if less than $\left.300 \mathrm{~cm}^{2}\right)$ does not exceed $8 \times 10^{5} \mathrm{~Bq} / \mathrm{cm}^{2}$ (20 microcurie $/ \mathrm{cm}^{2}$ ) for beta and gamma and low toxicity alpha emitters, or $8 \times 10^{4} \mathrm{~Bq} / \mathrm{cm}^{2}$ (2 microcurie/ $\left.\mathrm{cm}^{2}\right)$ for all other alpha emitters.

The shipper is responsible for ensuring that the material packaged meets the above requirements.

\subsubsection{Transportation}

Stacking of the cases during shipment is prohibited. The speed of the transport vehicle shall not exceed the posted speed limit at any time.

Transportation Requirements for low specific activity (LSA) Class 7 (radioactive) materials and surface contaminated objects (SCO) (49 C.FR 173.427).

(a) In addition to other applicable requirements specified in this subchapter, low specific activity (LSA) materials and surface contaminated objects ( $S C O$ ), unless excepted by paragraph (d) of this section, must be packaged in accordance with paragraph (b) or (c) of this section and must be transported in accordance with the following conditions: 
WHC-SD-TP-DAP-009 Rev. 0

(1) The external dose rate must not exceed an external radiation level of $10 \mathrm{mSv} / \mathrm{h}(1 \mathrm{rem} / \mathrm{h})$ at 3 meters from the unshielded material;

(2) The quantity of LSA and SCO material in any single conveyance must not exceed the limits specified in Table 9;

(3) LSA material and SCO that are or contain fissile material must meet the applicable requirements of $\$ 173.451$ (fissile requirements);

(4) Packages must meet the contamination control limits specified in $\$ 173.443$;

(5) External radiation levels must comply with 173.441; and

(6) For LSA material and SCO required by this section to be consigned as exclusive use:

(i) Shipments must be loaded by the consignor and unloaded by the consignee from the conveyance or freight container in which originally loaded;

(ii) There must be no loose Class 7 (radioactive) material in the conveyance, however, when the conveyance is the packaging there must be no leakage of Class 7 (radioactive) material from the conveyance;

(iii) Packages must be braced so as to prevent shifting of lading under conditions normally incident to transportation;

(iv) Specific instructions for maintenance of exclusive use shipment controls must be provided by the offeror to the carrier. such instructions must be included with the shipping paper information;

(v) Except for shipments of uncontrolled uranium or thorium ores, the transport vehicle must be placarded in accordance with subpart $F$ of Part 172 of this subchapter;

(vi) For domestic transportation only, packages are excepted from the marking and labeling requirements of this subchapter. However, the exterior of each nonbulk package must be stenciled or otherwise marked "Radioactive-LSA" or "Radioactive-SCO", as appropriate, and nonbulk packages that contain a hazardous substance must also be stenciled or otherwise marked with the letters "RQ" in association with the above description; and

(vii) [NA] (Air transport)

(b) Except as provided in paragraph (c) of this section, ISA material and SCO must be packaged as follows:

(1) In an industrial package (IP-1, IP-2 or IP-3; 173.411), subject to the limitations of Table 8 ; 
(2) [NA] (Type A package)

(3) For domestic transportation only, in a strong, tight package that prevents leakage of the radioactive content under normal conditions of transport. In addition to the requirements of paragraph (a) of this section, the following requirements must be met:

(i) The shipment must be exclusive use;

(ii) The quantity of Class 7 (radioactive) material in each packaging may not exceed an $A_{2}$ quantity.

(c) LSA-I and SCO-I (see 173.403), unless packaged in accordance with paragraph (b) of this section, must be packaged in bulk packagings in accordance with this paragraph. The shipment must be, in addition to complying with the applicable requirements of paragraph (a) of this section, exclusive use:

(1) Solids. Packages must be strong tight packagings, meeting the requirements of subpart $B$ of this Part, transported in a closed transport vehicle. The requirements of 173.410 do not apply.

\section{(2) [NA] (Liquids)}

(d) Except for transportation by aircraft, LSA material and SCO that conform to the provisions specified in 10 CFR 20.2005 are excepted from all requirements of this subchapter pertaining to Class 7 (radioactive) materials when offered for transportation for disposal or recovery. A material which meets the definition of another hazard class is subchapter relating to that hazard class.

(e) LSA and SCO that exceed the packaging limits in this section must be packaged in accordance with 10 CFR part 71.

(f) Tab7es 8 and 9 are as follows:

Table 8. Industrial Package Integrity Requirements for LSA Material and SCO.

\begin{tabular}{|c|c|c|}
\hline \multirow[b]{2}{*}{ Contents } & \multicolumn{2}{|c|}{ Industrial Packaging Type } \\
\hline & $\begin{array}{c}\text { Exclusive Use } \\
\text { Shipment }\end{array}$ & $\begin{array}{l}\text { Nonexclusive } \\
\text { Use Shipment } \\
\end{array}$ \\
\hline $\begin{array}{l}\text { LSA-I: } \\
\text { Solid } \ldots \ldots \ldots \ldots \\
\text { Liquid } \ldots \ldots \ldots \ldots \\
\text { LSA-II } \\
\text { Solid } \ldots \ldots \ldots \ldots \\
\text { Liquid and Gas } \ldots \\
\text { LSA-III } \ldots \ldots \ldots \ldots \ldots \\
\text { SCO-I } \ldots \ldots \ldots \ldots \ldots \ldots \\
\text { SCO } I I \ldots \ldots \ldots \ldots \ldots\end{array}$ & $\begin{array}{l}I P-1 \\
I P-1 \\
I P-2 \\
I P-2 \\
I P-2 \\
I P-1 \\
I P-2\end{array}$ & $\begin{array}{l}I P-I \\
I P-2 \\
I P-2 \\
I P-3 \\
I P-3 \\
I P-1 \\
I P-2\end{array}$ \\
\hline
\end{tabular}


Table 9. Conveyance Activity Limits for LSA Material and SCO.

\begin{tabular}{|c|c|}
\hline Nature of Material & $\begin{array}{c}\text { Activity Limit for } \\
\text { Conveyances }\end{array}$ \\
\hline 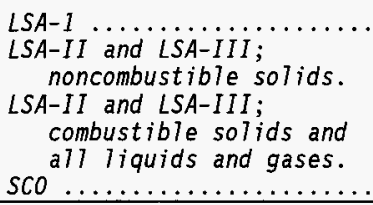 & $\begin{array}{l}\text { No Limit } \\
\text { No Limit } \\
100 \mathrm{~A}_{2} \\
100 \mathrm{~A}_{2}\end{array}$ \\
\hline
\end{tabular}

\subsubsection{Loading and Unloading}

Loading and unloading of the cases shall follow procedures developed by the facility using the cases.

\subsubsection{Tiedowns}

A tiedown system shatl be used to secure the cases to the transport vehicle(s) and shall be in accordance with the criteria of 49 CFR 393.102-104. For securement of the case to the transfer vehicle, strapping along with blocking and bracing is the recommended method.

\subsection{CONCLUSION}

It has been shown previously that the Hardigg cases may be used as packaging for the transport of radioactive material as an IP-1 or strong, tight container. The allowable radiological limits are determined by the method of transport (i.e., LSA-I, LSA-II, LSA-III, SCO-I, or SCO-II) and use of the IP-1/strong, tight container. The regulations, current as of April 1 , 1996, have been provided previously to aid in the determination of the most appropriate method of transport.

\subsection{REFERENCES}

49 CFR 173, 1996, "Shippers-General Requirements for Shipments and Packaging," Code of Federal Regulations, as amended.

49 CFR 393, 1996, "Parts and Accessories Necessary for Safe Operation," Code of Federal Regulations, as amended. 


\section{WHC-SD-TP-DAP-009 Rev. 0}

WHC-CM-2-14, Hazardous Material Packaging and Shipping, Westinghouse Hanford Company, Richland, Washington. 
WHC-SD-TP-DAP-009 Rev. 0

\section{APPENDIX}

HARDIGG CATALOG

$A-\mathbf{i}$ 


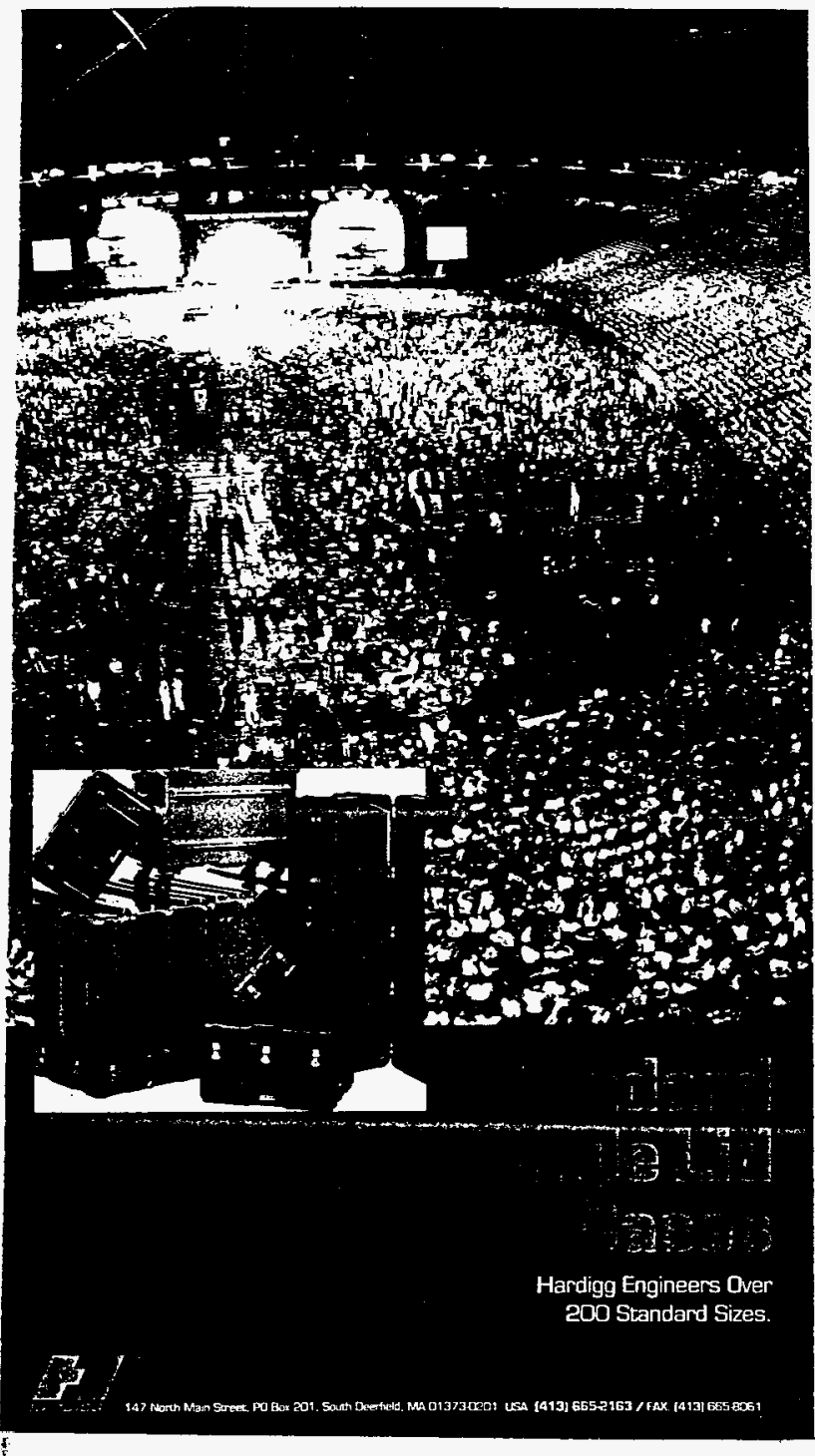

Giants Stadium Sixty-three thousand fans sromping shunder and screaming at the tops of their lungs jor Billy Joel and Elton Johnt. But it's not just the piano men they're waining for. A steep ticket price entitles them 10 see smoke fireworks and special effects provided in part by the most sophisticated largescreen display projector in the world valued at close to o hundred thousand dollars, the projector's sensitive high-tech precision optics con be dameged by exposuts to rain, dust, humidity on manhandling by roadies thathing io get to the nex gig bow does the projector sumive? It a standard single lid Hardsg Case An off-the. shelf sis with airtight gaske1 and configured fam interior and con protecsith 350 polind projec ior, which th housed inside the coniainet and remains there for safery. Engineered io protect, it

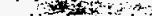
enables that one piece of equip$\Delta$ ousta

menito with and the rigors of a rock touk around the world,

bumped and ostled ligged inrough alpors ond hoisted

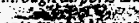

onto the 10 No manier what

happenectat the Meadowlands. thank for hot of Case, even the lain of ofd on Tokyo-r Sydret 2 thedoy the show. sydney, yenjoy the show.

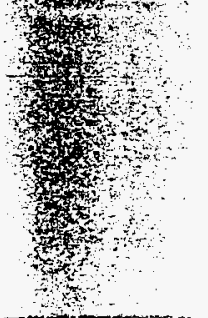
. 


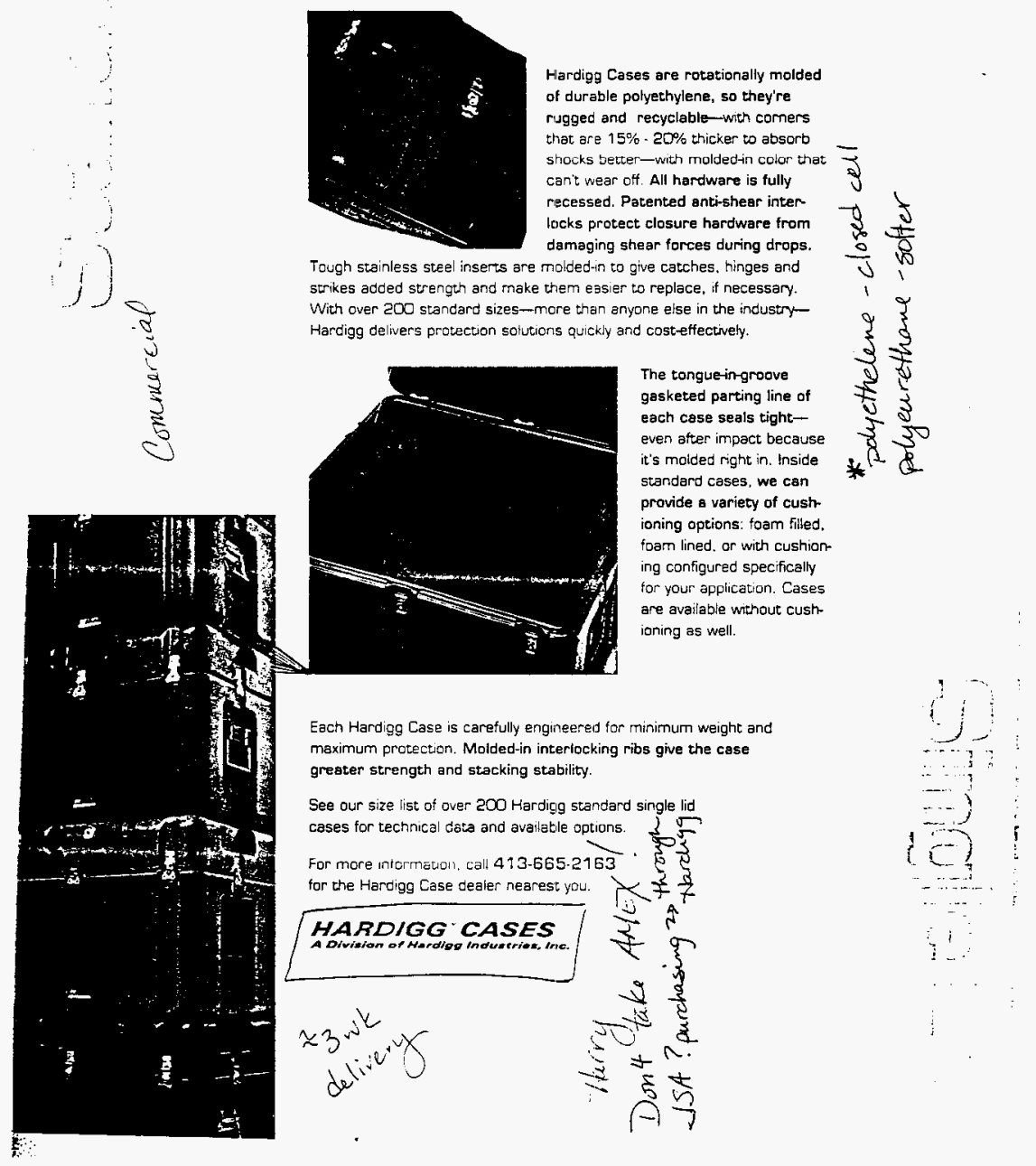


MEASURING GUIDE: STANDARD HARDIGG ${ }^{\text {" }}$ CASES

PART NUMBER EXAMPLE
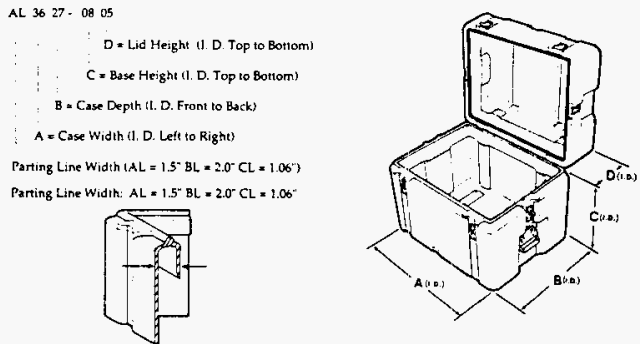

\section{MEASURING GUIDE: 19" RACKMOUNT ENCLOSURES}

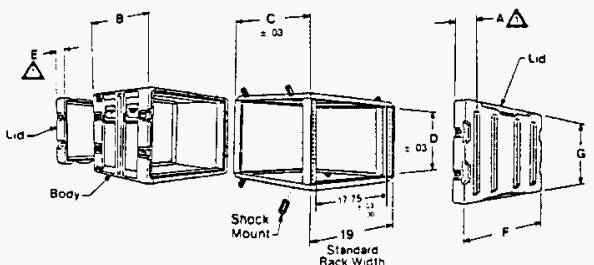

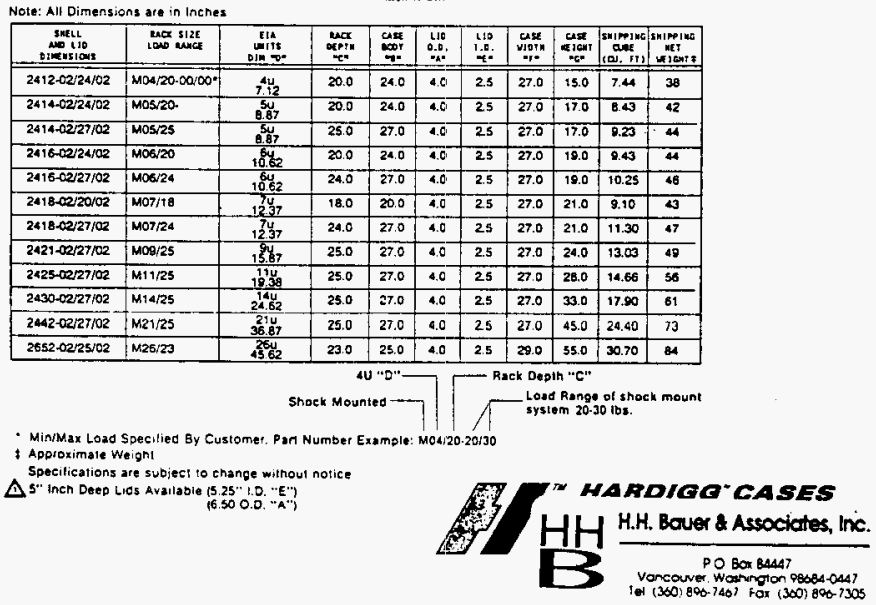




\begin{tabular}{|c|c|c|c|c|c|c|c|c|c|c|c|c|c|c|c|}
\hline \multirow{3}{*}{$\begin{array}{l}\text { CASE } \\
\text { AL1010-0904 }\end{array}$} & \multicolumn{3}{|c|}{ INSIDE DIM. } & \multicolumn{3}{|c|}{ OUTSIDE DIM. } & \multirow[b]{2}{*}{ Lbs. } & \multirow[b]{2}{*}{ CASE } & \multicolumn{3}{|c|}{ INSIDE DIM. } & \multicolumn{3}{|c|}{ OUTSIDE DIM. } & \multirow[b]{2}{*}{ Lbs. } \\
\hline & $L$ & $w$ & $H$ & $\mathbf{L}$ & $w$ & $H$ & & & $\mathbf{L}$ & $W$ & & $\mathbf{L}$ & $w$ & $\mathrm{H}$ & \\
\hline & 10 & 10 & 13 & 13 & 13 & 14.3 & 9.8 & AL2216-0805 & 22 & 16 & 13.5 & 25 & 19 & 15 & 20.9 \\
\hline AL1010-0905 & 10 & 10 & 14 & 13 & 13 & 15.6 & 10.6 & AL2216-1205 & 22 & 16 & 17 & 25 & 19 & 19 & 22.9 \\
\hline AL1010-1404 & 10 & 10 & 18 & 13 & 13 & 19.3 & 11.5 & AL22:21-0604 & 22.5 & 21 & 10.5 & 25.5 & 24 & 12.3 & 24.0 \\
\hline AL1010-1405 & 10 & 90 & 19 & 13 & 13 & 20.6 & 124 & AL2221-0605 & 22.5 & 21 & 11.5 & 25.5 & 24 & 12.3 & 24.8 \\
\hline CL1 109-0303HL & 11 & 9 & 6 & 13 & 11 & 6.9 & 5.7 & AL22:21-0614AC & 22.5 & 21 & 20.5 & 25.5 & 24 & 22.5 & 26.8 \\
\hline AL1212-0404 & 12 & 12 & 8 & 15 & 15 & 9.6 & 10.6 & AL22:21-1204 & 22.5 & 21 & 16 & 25.5 & 24 & 17.9 & 26.8 \\
\hline AL1212-0405 & 12 & 12 & 9 & 15 & 15 & 10.8 & 10.8 & AL2221-1205 & 22.5 & 21 & 17 & 25.5 & 24 & 19.3 & 27.7 \\
\hline AL1212-1504 & 12 & 12 & 19 & 15 & 15 & 20.6 & 14.7 & AL22:21-1214AC & 22.5 & 21 & 26 & 25.5 & 24 & 28 & 29.6 \\
\hline AL1212-1505 & 12 & 12 & 20 & 15 & 15 & 21.8 & 14.9 & AL2221-1804 & 22.5 & 21 & 22.5 & 25.5 & 24 & 24.5 & 33.2 \\
\hline AL1212-1904 & 12 & 12 & 23 & 15 & 15 & 24.3 & 16.8 & AL22:21-1805 & 22.5 & 21 & 23.5 & 25.5 & 24 & 25.9 & 34.1 \\
\hline AL1212.1905 & 12 & 12 & 24 & 15 & 15 & 25.6 & 17.0 & $\because$ AL2221-1814AC & 22.5 & 21 & 32.5 & 25.5 & 24 & 34.7 & 36.0 \\
\hline CL1412-0502 & 14 & 12 & 7 & 16 & 14 & 8 & 11.7 & AL22:21-2804 & 22.5 & 21 & 32.5 & 25.5 & 24 & 34 & 39.8 \\
\hline AL1413-0505 & 14.5 & 13 & 10 & 17.5 & 16 & 12.2 & 13.9 & AL22:21-2805 & 22.5 & 21 & 33.5 & 25.5 & 24 & 35.4 & 40.6 \\
\hline AL1413-1005 & 14.5 & 13 & 15 & 17.5 & 16 & 17 & 16.5 & $A \operatorname{Lin} 21-2814 A C$ & 225 & 21 & 42.5 & 25.5 & 24 & 44.2 & 42.6 \\
\hline AL1413-2105 & 14.5 & 13 & 26 & 17.5 & 16 & 27.7 & 19.4 & AL23:13-1004 & 23 & 13 & 14 & 26 & 16 & 15.2 & 19.2 \\
\hline AL1414-0705 & 14 & 14 & 12 & 17 & 17 & 13.7 & 14.6 & AL23-5-2507 & 23 & 18 & 32 & 26 & 18 & 33 & 32.2 \\
\hline AL1616-0404 & 16 & 16 & 8 & 19 & 19 & 9.7 & 12.3 & AL23:6-0604 & 23 & 16 & 10 & 26 & 19 & 11.5 & 19 \\
\hline AL1616-0405 & 16 & 16 & 9 & 19 & 19 & 10.8 & 13.7 & $A L 2318-1205$ & 23 & 18 & 17 & 26 & 21 & 19 & 26.1 \\
\hline AL1616-0412AC & 16 & 16 & 16 & 19 & 19 & 17.3 & 17.0 & AL2318-1705 & 23 & 18 & 22 & 26 & 21 & 24 & 29.1 \\
\hline AL1616-0504 & 16 & 16 & 9 & 19 & 19 & 10.7 & 13.9 & CL2406-0303 & 24 & 6 & 6 & 26 & 8 & 6.5 & 9.0 \\
\hline AL1616-0505 & 16 & 16 & 10 & 19 & 19 & 12 & 15.3 & AL2414-0509AC & 24.9 & 14.9 & 14 & 27.9 & 17.9 & 16 & 28.3 \\
\hline AL1616-0512AC & 16 & 16 & 17 & 19 & 19 & 18.8 & 18.5 & AL2423-0904 & 24 & 23 & 13 & 27 & 26 & 14.8 & 27.6 \\
\hline AL1616-1004 & 16 & 16 & 14 & 19 & 19 & 15.7 & 16.2 & AL2423.0911AC & 24 & 23 & 20 & 27 & 26 & 22.7 & 31.8 \\
\hline AL1616-1005 & 16 & 16 & 15 & 19 & 19 & 16.8 & 17.6 & $A L 24: 3-1104$ & 24 & 23 & 15 & 27 & 26 & 17 & 28.0 \\
\hline AL1616-1012AC & 16 & 16 & 22 & 19 & 19 & $23.3^{\circ}$ & 20.8 & AL242:3-1111AC & 24 & 23 & 22 & 27 & 26 & 24.8 & 32.3 \\
\hline AL1616-1204 & 16 & 16 & 15.7 & 19 & 19 & 17 & 16.7 & AL2617-0604 & 26 & 17 & 10 & 29 & 20 & 11.8 & 23.2 \\
\hline AL1616-1205 & 16 & 16 & 16.7 & 19 & 19 & 18.3 & 18.0 & AL $2617-1104$ & 26 & 17 & 15 & 29 & 20 & 16.8 & 28.4 \\
\hline$A L 1616-1212 A C$ & 16 & 16 & 23.7 & 19 & 19 & 24.5 & 21.3 & AL262:4-0805 & 26 & 24 & 13 & 29 & 27 & 16.8 & 32.9 \\
\hline AL1616-1804 & 16 & 16 & 22.5 & 19 & 19 & 23.3 & 20.6 & $A L 262: 4-0824 A C$ & 26 & 24 & 32 & 29 & 27 & 35.8 & 46.0 \\
\hline AL1616-1805 & 16 & -16 & 23.5 & 19 & 19 & 25 & 220 & AL262.4-1205 & 26 & 24 & 17 & 29 & 27 & 20.8 & 35.6 \\
\hline AL1616-1812AC & 16 & 16 & 30.5 & 19 & 19 & 31.5 & 25.3 & AL2624-1224AC & 26 & 24 & 36 & 29 & 27 & 39.8 & 48.7 \\
\hline CL1713-0403 & 17 & 13 & 7 & 19 & 15 & 8 & 9.6 & AL2624-1805 & 26 & 24 & 23 & 29 & 27 & 26.8 & 39.6 \\
\hline CL1713-0408AC & 17 & 13 & 12 & 19 & 15 & 13 & 11.0 & AL2624-T824AC & 26 & 24 & 42 & 29 & 27 & 45.8 & 52.8 \\
\hline CL1715-1004 & 17 & 15 & 14 & 19 & 17. & 15 & 12.6 & AL2624-2705 & 26 & 24 & 32.5 & 29 & 27 & 36.3 & 45.2 \\
\hline AL1717-0909AC & 17 & 17 & 18 & 20 & 20 & 20 & 18.8 & AL2624-2724AC & 26 & 24 & 51.5 & 29. & 27 & 55.3 & 58.3 \\
\hline AL1814-0504 & 18 & 14.5 & 9 & 21 & 17.5 & 10.7 & 14.4 & AL2727-0404 & 27 & 27 & 8 & 30 & 30 & 10.5 & 32.2 \\
\hline AL1814-0505 & 18 & 14.5 & 10 & 21 & $17.5^{\circ}$ & 12 & 15.6 & AL2727-0405 & 27 & 27 & 9 & 30 & 30 & 11.3 & 33.5 \\
\hline ALL1814-1504 & 18 & 14.5 & 19 & 21 & 17.5 & 20.3 & 19.3 & AL2727-0409AC & 27 & 27 & 13 & 30 & 30 & 15.5 & 35.9 \\
\hline AL1814-1505 & 18 & $\$ 4.5$ & 20 & 21 & 17.5 & 21.8 & 20.5 & AL2727-0414AC & 27 & 27 & 18 & 30 & 30 & 20.5 & 39.7 \\
\hline AL1814-2204 & 18 & 14.5 & 26 & 21 & 17.5 & 27.6 & 23.4 & AL2727-0504 & 27 & 27 & 9 & 30 & 30 & 11.3 & 32.2 \\
\hline AL1814-2205 & 18 & 14.5 & 27 & 21 & 17.5 & 28.8 & 24.6 & AL2727-0505 & 27 & 27 & 10 & 30 & 30 & 12.5 & 33.5 \\
\hline A.L1818-0603HL & 18 & 18 & 9 & 21 & 21 & 10.7 & 17.9 & AL2727-0509AC & 27 & 27 & 14 & 30 & 30 & 16.5 & 35.9 \\
\hline CL2012-0902 & 20 & 12 & 11 & 22 & 14 & 128 & 19.1 & AL2727-0514AC & 27 & 27 & 19 & 30 & 30 & 22.3 & 39.7 \\
\hline A.L $2013-0403$ & 20 & 13 & 7 & 23 & 16 & 8.7 & 14.4 & AL2727-0904 & 27 & 27 & 13 & 30 & 30 & 15.3 & 34.5 \\
\hline AL2013-0903 & 20 & 13 & 12 & 23 & 16 & 14 & 16.8 & AL2727-0905 & 27 & 27 & 14 & 30 & 30 & 16.6 & 35.9 \\
\hline AL2015-0503HL & 20 & 15 & 8 & 23 & 18 & 9. & 18.9 & AL2727-0909AC & 27 & 27 & 18 & 30 & 30 & 20.3 & 38.2 \\
\hline AL2015-1503HL & 20 & 15 & 18 & 23 & 18 & 19 & 24.7 & AL2727-0914AC & 27 & 27 & 23 & 30 & 30 & 25.3 & 42.0 \\
\hline AL2020-1305 & 20 & 20 & 18 & 23 & 23 & 20 & 25.7 & AL 2727-1404 & 27 & 27 & 18 & 30 & 30 & 20.5 & 38.3 \\
\hline AL2216-0505 & 22 & 16 & 10 & 25 & 19 & 11.3 & 18.5 & AL272: $: 1405$ & 27 & 27 & 19 & 30 & 30 & 21.8 & 39.7 \\
\hline
\end{tabular}


WHC-SD-TP-DAP-009 Rev. 0

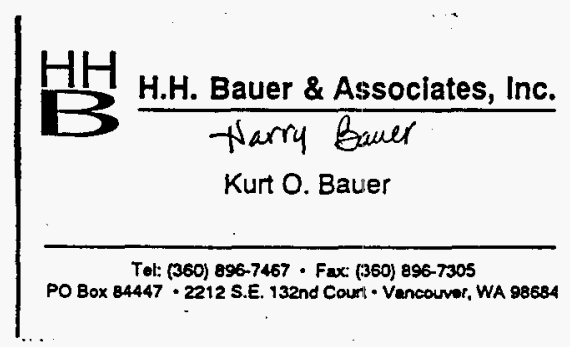




\begin{tabular}{|c|c|c|c|c|c|}
\hline \multicolumn{6}{|c|}{ DISTRIBUTION SHEET } \\
\hline \multirow{2}{*}{$\begin{array}{l}\text { To } \\
\text { Distribution }\end{array}$} & \multirow{2}{*}{\multicolumn{3}{|c|}{$\begin{array}{l}\text { From } \\
\text { Packaging Engireering }\end{array}$}} & \multicolumn{2}{|c|}{ Page 1 of 1} \\
\hline & & & & \multicolumn{2}{|c|}{ Date $05 / 31 / 96$} \\
\hline \multicolumn{4}{|c|}{ Project Title/Work Order } & \multicolumn{2}{|c|}{ EDT No. 615809} \\
\hline \multicolumn{4}{|c|}{$\begin{array}{l}\text { Documentation and Analysis for Packaging for the Hardigg Cases } \\
\text { (WHC-SD-TP-DAP-009) }\end{array}$} & N No. $\mathrm{N} / 1$ & \\
\hline Name & MSIN & $\begin{array}{l}\text { Text } \\
\text { With All } \\
\text { Attach. }\end{array}$ & Text Only & $\begin{array}{l}\text { Attach./ } \\
\text { Appendix } \\
\text { Only }\end{array}$ & $\begin{array}{l}\mathrm{EDT} / \mathrm{ECN} \\
\text { Only }\end{array}$ \\
\hline $\begin{array}{l}\text { B. D. Flanagan } \\
\text { R. L. Clawson } \\
\text { J. G. Field } \\
\text { C. R. Hoover } \\
\text { W. R. Jaquish } \\
\text { D. W. McNally } \\
\text { R. J. Smith } \\
\text { A. F. Wellner } \\
\text { Central Files } \\
\text { Eoetment Processing-Eenter } \\
\text { WHC-SD-TP-DAP-009 File } \\
\end{array}$ & $\begin{array}{l}\text { G1-11 } \\
G 1-13 \\
G 1-11 \\
G 1-11 \\
H 5-70 \\
\text { G1-11 } \\
\text { G1-11 } \\
\text { H5-70 } \\
\text { A3-88 } \\
\text { A3 }-94 \\
\text { G1-11 }\end{array}$ & $\begin{array}{l}x \\
x \\
x \\
x \\
x \\
x \\
x \\
x \\
x \\
x-2- \\
x \\
\end{array}$ & & & \\
\hline
\end{tabular}

